\title{
Upper Gastrointestinal Bleeding Treatment in Children - A Difficult Challenge for the Doctor
}

\author{
Sur Genel ${ }^{1,2 *}$, Sur M Lucia ${ }^{1}$, Sur G Daniel ${ }^{1}$ and Floca Emanuela ${ }^{1}$ \\ ${ }^{1}$ University of Medicine and Pharmacy, IuliuHatieganu, Cluj-Napoca, Romania \\ ${ }^{2}$ Emergency Clinical Hospital for Children, Cluj-Napoca, Romania
}

*Corresponding author: Sur Genel, University of Medicine and Pharmacy, uliu Hatieganu, Cluj-Napoca, Romania, Tel: 0040724504964; E-mail: surgenel@yahoo.com

Received date: June 13, 2016; Accepted date: Jun 14, 2016; Published date: Jun 17, 2016

Copyright: ( 2016 Sur Genel, et al. This is an open-access article distributed under the terms of the Creative Commons Attribution License, which permits unrestricted use, distribution, and reproduction in any medium, provided the original author and source are credited.

\begin{abstract}
In order to make the appropriate treatment is necessary an accurate diagnosis. This is also true for upper gastrointestinal bleeding in children. It is not always easy to sustain the diagnosis, but using current methods we can reach etiologic diagnosis. After diagnosis the best treatment options are choosing. These must be both efficient and with fewer side effects. Upper gastrointestinal hemorrhage treatment takes into account two situations: patients with hemodynamic instability with large blood loss and patients with hemodynamic stability. Patients with important upper gastrointestinal bleeding with hemorrhagic shock need resuscitation and should be stabilized prior to endoscopy.
\end{abstract}

Keywords: Children; Treatment; Bleeding; Gastrointestinal

\section{Introduction}

Upper gastrointestinal bleeding represents the loss of blood in the digestive tract from the esophagus to the Treitz ligament. Upper gastrointestinal bleeding is one of the most severe problems that must be diagnosed and treated by pediatric gastroenterologist [1].

In case of a child with upper gastrointestinal bleeding should be established: the source, extent, duration, frequency of bleeding. In the case of a child with upper gastrointestinal bleeding should be established: the source, amount, duration, and frequency of bleeding. Besides bleeding, patients may experience gastrointestinal manifestation such as diarrhea, constipation, vomiting, abdominal pain, or the presence of systemic signs such as fever, pallor, palpitations, cold extremities, and rash [2].

First evaluation of the patients with upper gastrointestinal bleeding sets hemodynamic status of patient and whether it is necessary hemodynamic resuscitation. Resuscitation is important in children and should be done as quickly as possible. The causes of bleeding are established in the shortest time possible. If we are in the case of brisk bleeding or unexplained or when there are signs of shock upper gastrointestinal endoscopy is practiced. In some cases the source of bleeding can be detected and treated by endoscopic procedures. Endoscopic evaluation and treatment are initiated after the patient is stabilized or while $24-48$ hours $[3,4]$.

\section{Treatment}

Children with upper gastrointestinal bleeding (UGB) can present stable conditions or different degrees of hemodynamic instability, reaching the stage of shock $[3,4]$.

The evaluation of these patients should start with an assessment of hemodynamic state of patients. The initial evaluation includes vital signs such as heart rate, blood pressure, and capillary refill. Such patients should be admitted in an intensive care unit to monitor vital functions including circulation and breathing. During the initial evaluation, two vein lines are chosen for administration of fluids and transfusion $[5,6]$.

\begin{tabular}{|l|l|l|}
\hline Name & Dose & Indications \\
\hline Fluid replacement & $\begin{array}{l}\text { Ringer solutions or saline solutions: } \\
-20 \mathrm{~mL} / \mathrm{Kg} \text { bolus in first } 5 \text { minutes, without exceeding } 80 \mathrm{ml} / \mathrm{kg} \\
\text { in the first } 20 \text { minutes } \\
- \text { in patients with heart failure dose is } 5-10 \mathrm{ml} / \mathrm{kg} \text { bolus }\end{array}$ & $\begin{array}{l}\text { Hemodynamically } \\
\text { patients }\end{array}$ \\
\hline Proton pump inhibitors & $\begin{array}{l}\text { Omeprazole } 1 \mathrm{mg} / \mathrm{kg} / 24 \mathrm{~h} \text { iv in a single daily dose or po } \\
\text { divided in } 1 \text { or } 2 \text { doses }\end{array}$ & $\begin{array}{l}\text { Peptic ulcer } \\
\text { Stress gastritis }\end{array}$ \\
\hline H2 receptor antagonists & $\begin{array}{l}\text { Ranitidine: } \\
- \text { oral } 2-4 \mathrm{mg} / \mathrm{kg} / \text { day in } \\
2 \text { doses; } \\
- \text { iv } 2-4 \mathrm{mg} / \mathrm{kg} / \text { day divided every } 6 \text { to } 8 \text { hours }\end{array}$ & $\begin{array}{l}\text { Peptic ulcer } \\
\text { Stress gastritis }\end{array}$ \\
\hline
\end{tabular}


Citation: Sur Genel, Sur M Lucia, Sur G Daniel and Floca Emanuela (2016) Upper Gastrointestinal Bleeding Treatment in Children - A Difficult Challenge for the Doctor. Pharm Anal Acta 7: e186. doi:10.4172/2153-2435.1000e186

Page 2 of 2

\begin{tabular}{|l|l|l|l|}
\hline & $\begin{array}{l}\text { - maximum dose } \\
200 \mathrm{mg} / \mathrm{day}\end{array}$ & \\
\hline Vasoactive agents & $\begin{array}{l}\text { Octreotide: } 1 \mu \mathrm{g} / \mathrm{Kg} \text { iv bolus, followed by } 1-2 \mu \mathrm{g} / \mathrm{Kg} / \mathrm{hour} \text { as a } \\
\text { continuous iv infusión } \\
\text { - maximum } 50 \mu \mathrm{g} / \mathrm{hour}\end{array}$ & $\begin{array}{l}\text { Bleeding from esophageal } \\
\text { varices }\end{array}$ \\
\hline Beta blockers & $\begin{array}{l}\text { Propranolol: } \\
0.5-2 \mathrm{mg} / \mathrm{kg} \mathrm{/} \mathrm{day,} \mathrm{orally,} \mathrm{divided} \mathrm{in} 2 \text { to } 4 \text { doses without } \\
\text { reducing the heart rate by> } 75 \% \text { from baseline }\end{array}$ & $\begin{array}{l}\text { Portal hypertension, } \\
\text { esophageal varices }\end{array}$ \\
\hline
\end{tabular}

Table 1: Upper gastrointestinal bleeding treatment: drugs and doses

In case of patients with hemodynamic instability resuscitation is prior to diagnosis studies.

Blood transfusion is indicated in unstable patients with hemoglobin $<8 \mathrm{~g} / \mathrm{dL}$. Patients who have brisk bleeding and coagulopathy receive fresh frozen plasma. If platelets are less than $30,000 / \mathrm{ml}$ transfusion of platelets is indicated. After stabilizing the patient begins taking proton pump inhibitors, $\mathrm{H} 2$ receptor antagonists, vasoactive drugs, and betablockers, depending on the indication $[7,8]$.

In patients who are hemodynamically stable the treatment begins with proton pump inhibitors and, depending on the situation, with $\mathrm{H} 2$ receptor antagonists, vasoactive drugs, beta-blockers $[9,10]$.

In case of bleeding esophageal varices the upper gastrointestinal endoscopy has both diagnostic and therapeutic role. Endoscopic treatment methods include ligatures, hemostatic clips, coagulation and sclerotherapy. If bleeding is not controlled by endoscopic procedure, the case must be evaluated for surgical treatment $[1,4]$.

\section{References}

1. Gralnek IM, Dumonceau JM, Kuipers EJ, Lanas A, Sanders DS, et al. (2015) Diagnosis and management of nonvariceal upper gastrointestinal hemorrhage: European Society of Gastrointestinal Endoscopy (ESGE) Guideline. Endoscopy 47: a1-46.
2. Sur G (2016) Gastrointestinal Bleeding in Children can have Many Causes. Pharm Anal Acta 7.

3. Khamaysi I, Gralnek IM (2013) Acute upper gastrointestinal bleeding (UGIB) - Initial evaluation and management. Best Pract Res Clin Gastroenterol 27: 633-638.

4. Owensby S, Taylor K, Wilkins T (2015) Diagnosis and management of upper gastrointestinal bleeding in children. J Am Board Fam Med 28: 134-145.

5. Dworzynski K, Pollit V (2012) Management of acute upper gastrointestinal bleeding: summary of NICE guidance. BMJ 344.

6. Colle I, Wilmer A, Le Moine O, Debruyne R, Delwaide J, et al. (2011) Upper gastrointestinal tract bleeding management : Belgian guidelines for adults and children. Acta Gastroenterol Belg 74: 45-66.

7. Càndid Villanueva, Alan Colomo, Alba Bosch, Mar Concepción, Virginia Hernandez-Gea, et al. (2013) Transfusion Strategies for Acute Upper Gastrointestinal Bleeding. N Engl J Med 368: 11-21.

8. Neidich GA, Cole SR (2014) Gastrointestinal bleeding. Pediatr Rev 35: 243.

9. Singhi S, Jain P, Jayashree M, Lal S (2013) Approach to a Child with Upper Gastrointestinal Bleeding. The Indian Journal of Pediatrics 80: 326-333.

10. Eroglu Y, Emerick KM, Whitingon PF, Alonso EM (2004) Octreotide therapy for control of acute gastrointestinal bleeding in children. J Pediatr Gastroenterol Nutr 38: 41. 